\title{
Peertechz
}

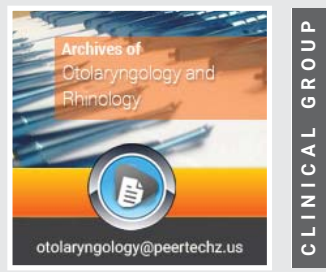

\section{Diagnosis of the pathophysiology of chronic mucosal diseases of allergic rhinitis, asthma and otitis media as seen by an otolaryngologist}

\section{David S Hurst ${ }^{1 \star}$ and Alan B McDaniel ${ }^{2}$}

${ }^{1} \mathrm{MD}, \mathrm{PhD}$, Department of Otolaryngology, Tufts University, Boston, MA, USA

2University of Louisville, Kentucky, USA
Received: 17 November, 2021

Accepted: 11 December, 2021

Published: 13 December, 2021

*Corresponding author: David S Hurst, MD, PhD, Department of Otolaryngology, Tufts University, Boston, MA, 43 Carson Drive, Gorham, ME 04038, USA, Tel: 01-207-578-0743;

E-mail: oto72hurst@gmail.com

ORCID: https://orcid.org/0000-0002-1216-9861

Copyright: (C) 2021 Hurst DS, et al. This is an openaccess article distributed under the terms of the Creative Commons Attribution License, which permits unrestricted use, distribution, and reproduction in any medium, provided the original author and source are credited.

https://www.peertechzpublications.com

Check for updates

\section{Abbreviations}

ETD: Eustachian Tube Dysfunction; SPT: Skin Prick Test; ITD: Intradermal Skin Testing; ECP: Eosinophil Cationic Protein.

Otolaryngologists, like Pediatricians, often see patients with chronic rhino-sinusitis and draining ears. Surgeons can offer various procedures, from simple tympanostomy tubes to advanced sinus and turbinate operations, in which significant portions of bone and mucosa are removed. The rates of reinfection are often reduced [1] but failures occur.

All agree that surgery would rarely be necessary if early identification of the underlying pathophysiology could guide preventative treatment. Allergic reactions can affect any organ, including the eyes, nose and sinuses, middle ears and mastoids, pharynx and larynx, lower airway, skin and gut. The middle ear and sinuses are embryologically homologous [2]. The 2016 AAO-HNS guidelines [3] emphasize the "unified airway" of respiratory mucosa linking the mastoid sinuses, middle ears, Eustachian tubes, nose and sinuses with the pharynx, larynx and lower airway with similar cellular responses leading to inflammation. They state that the middle ear is part of the unified airway, and "like other parts of respiratory mucosa, the mucosa lining the middle ear cleft is capable of an allergic response"[3].

The answer to the question regarding recurrent Eustachian Tube Dysfunction (ETD), sinusitis and polyps require an understanding of the Th1 and Th2 helper cell pathophysiology of the mucous membrane itself. Allergy, a Th2 response, adds unique co-morbidity and is by far greater risk for inflammation than any other identified factors [4]. The bacteria cultured are opportunists.

In the mucosa of allergic individuals, the sinuses and middle ear have all been shown to have degranulating mast cells and eosinophils [4]. which are genetically programmed to be hyperreactive on exposure to an allergen, these cells activate and participate in a type I IgE-mediated Th-2 driven inflammatory reaction [5]. Atopy involves a Th2 response whose related symptoms are deemed "allergic" [6]. They release various inflammatory mediators that create an environment of mucostasis, bacterial overgrowth, and chronic inflammation [7]. This Th2 response uniquely adds co-morbidity and is a much greater risk for inflammation than any other identified factor [4]. Indeed, the pathophysiology of allergic rhinitis, chronic sinusitis, asthma and ETD are associated with positive in vivo or in vitro tests for IgE mediated hypersensitivity $[7,8]$.

Atopy has been defined as "the propensity of an individual to develop IgE antibodies" [6]. Indicators of a Th-2 driven, IgE-mediated inflammatory allergic response are mast cells [9] with their mediator tryptase and degranulating eosinophils [10]. Both are present in a majority of ears with chronic effusion [10] - as well as in the sinuses and lungs of allergic individuals. Their actions predispose allergic patients towards Eustachian Tube Dysfunction (ETD), recurrent sinusitis, often asthma and nasal polyps. Data representing over 1.4 billion pediatric visits ${ }^{1}$ and a meta-analysis link allergic rhinitis to ETD and otitis media with effusion [11]. 


\section{A review of the cells involved in allergic middle ear disease}

Some have questioned the causal linkage of atopy/ allergic hypersensitivity and ETD/ chronic otitis media with effusion. First, based on objective allergy testing, the majority of OME patients are atopic [12]. Secondly, the current best evidence supports this association: De Corso's systematic review of 3,010 papers provides an in depth explanation of physiopathology factors linking allergy to increased risk of middle ear inflammation [13].

Hurst and Venge studied 97 children with OME, of whom $81 \%$ were atopic [10]. In middle ear fluids, allergic children had significantly higher eosinophil cationic protein (ECP) and tryptase than non-atopic children $(\mathrm{P}<0.001)$, indicating $\mathrm{Th}-2$ mediated eosinophil and mast cell activity. Tryptase was $>2$ $\mathrm{mg} / \mathrm{l}$ in $64 \%(23 / 36)$ of atopic patients [10]. As a marker of atopy among patients with non-purulent effusion, ECP had a positive predictive value of $97.1 \%$ and a diagnostic sensitivity of $86 \%$ [10]. Cell kinetics would suggest that these elevated levels of ECP and tryptase produce an active inflammatory process [14].

\section{Testing and Therapy}

The optimal therapy for an allergic condition is successful hypo-sensitization immunotherapy [15]. Treatment success begins with accurate allergy tests that establish the correct diagnosis - but tests are imperfect. Clinicians see patients with typical symptoms and signs of allergy, who respond to allergy medications but are reportedly negative upon allergy testing.

The basic question underlying this conundrum is: What type of allergy testing was done? Skin Prick Tests (SPT) introduce antigen at approximately 1:65,000 w/v. Intradermal Dilution Testing (IDT) injects antigens diluted 5-fold, from 1:65,000 to $1: 500 \mathrm{w} / \mathrm{v}$. The stronger antigen concentrations used in IDT promise greater sensitivity than SPT.

Our recent report of 371 patients, comparing SPT and IDT test results and treatment outcomes provided evidence that IDT offers superior sensitivity, no false-positive results [16]. We found that of the 3133 positive IDT antigen tests, only $12 \%$ (365) were detectable by SPT. IDT identified an additional 6.9 allergens per patient (Figure 1). Adding IDT tests following negative SPT more than tripled the number of detected allergens, doubled the number of people successfully treated with immunotherapy and increased the number of children diagnosed as being allergic by $58 \%$ [16]. Treatment outcomes showed equal improvement in the "high-sensitivity" and the "low-sensitivity" (SPT-negative, suspected false-positive) groups. Importantly, there was no difference in the failure rates between groups $(5.1 \%$ vs. $5.7 \%)$. The results of this study support our hypothesis: The increased sensitivity of IDT compared to SPT is clinically relevant in patients with classic allergic diseases of chronic rhinitis, ETD and asthma.

Reliance on the insensitive SPT may explain why many otolaryngologists find their clinical impression of allergy is

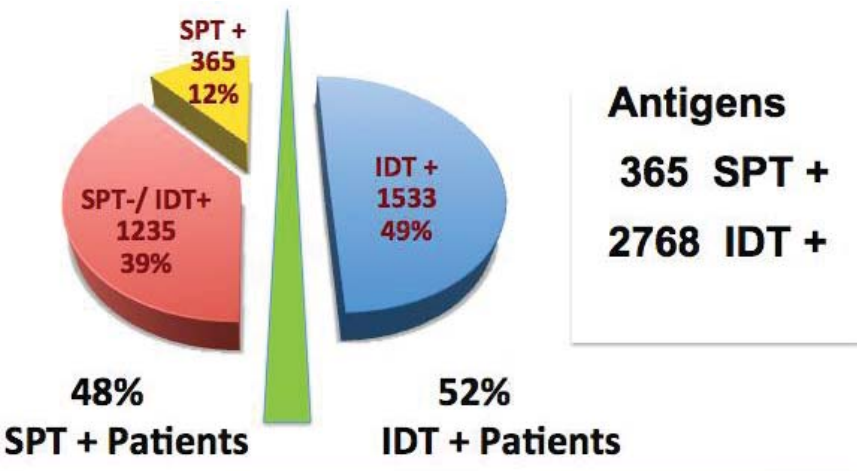

Figure 1: Effect of adding IDT to SPT total of 3133 Allergens Discovered. IDT identified 1235 more treatable allergens among SPT+ patients (groups D\&E) than did SPT alone (365) (Chi-Square $p<0.001,95 \% \mathrm{Cl}:-0.47,-0.36$ ), (odds ratio 0.09 ; 95\%CL: 0.05 to 0.15 ).

often not supported by skin testing. Thus, their patients are termed "chronic, non-allergic" and they doubt their diagnostic acumen. This can also explain why many otolaryngologists fail to include allergy in their differential diagnosis of ETD/ OME, as several authors have documented to be true $[7,11,12,13]$.

Importantly, as therapy is based on the identification of specific positive antigens, patients found to be negative by SPT testing can never benefit from immunotherapy if they are incorrectly labeled as "non-allergic". Physicians need to insist on the best science in order to provide the best therapy.

\section{References}

1. Koivuniemi $P$ (1988) Secretory otitis media and mastoid pneumatization A clinical study with long-term follow up.: Helsinki, Yliopistopaino. Link: https://bit.ly/3IMW7ZK

2. Cappello ZJ, Minutello K, Dublin AB (2021) Anatomy, Head and Neck, Nose Paranasal Sinuses. In: StatPearls [Internet]. Treasure Island (FL): StatPearls Publishing. Link: https://bit.ly/3ysTury

3. Rosenfeld RM, Shin JJ, Schwartz SR, Coggins R, Gagnon L, et al. (2016) Clinical Practice Guideline: Otitis Media with Effusion Executive Summary (Update) Otolaryngol Head Neck Surg 154: 201-214. Link: https://bit.ly/3DTbJHA

4. Hurst DS, Deene CM (2020) The Relation of Allergy to Eustachian Tube Dysfunction and the Subsequent Need for Insertion of Pressure Equalization Tubes. Ear Nose Throat J 99: 39S-47S. Link: https://bit.ly/3GHRxKJ

5. Pauwels R (1995) Future of anti-inflammatory therapy in asthma. Allergy 50 27-31.

6. Pepys J (1994) "Atopy": a study in definition. Allergy 49: 397-399.

7. Cheng X, Sheng H, Ma R, Gao Z, Han Z, et al. (2017) Allergic rhinitis and allergy are risk factors for otitis media with effusion: A meta-analysis. Allergol Immunopathol (Madr) 45: 25-32. Link: https://bit.ly/3oPpkLM

8. Hurst DS (2011) The role of allergy in otitis media with effusion. Otolaryngol Clin North Am 44: 637-654. Link: https://bit.ly/3GEkvel

9. Hurst DS, Amin K, Sevéus L, Venge P (1999) Evidence of mast cell activity in the middle ear of children with otitis media with effusion. Laryngoscope 109: 471-477. Link: https://bit.ly/3m1EoEa

10. Hurst DS, Venge P (2000) Evidence of eosinophil, neutrophil, and mast-cell mediators in the effusion of OME patients with and without atopy. Allergy 55 : 435-441. Link: https://bit.ly/3pTIxLw 
11. Roditi RE, Veling M, Shin JJ (2016) Age: An effect modifier of the association between allergic rhinitis and Otitis media with effusion. Laryngoscope 126: 1687-1692. Link: https://bit.ly/321lyFe

12. Luong A, Roland PS (2008) The link between allergic rhinitis and chronic otitis media with effusion in atopic patients. Otolaryngol Clin North Am 41: 311-323. Link: https://bit.ly/3ET53ug

13. De Corso E, Cantone E, Galli J, Seccia V, Lucidi D, et al. (2020) A Otitis media in children: which phenotypes are most linked to allergy? A systematic review. Authorea 32: 524-534. Link: https://bit.ly/3oMTGyq

14. Demoly P, Crampette L, Mondain M, Campbell AM, Lequeux N, et al. (1994)
Assessment of inflammation in noninfectious chronic maxillary sinusitis. $J$ Allergy Clin Immunol 94: 95-108. Link: https://bit.ly/31Pht8c

15. Jacobsen L, Wahn U, Bilo MB (2012) Allergen-specific immunotherapy provides immediate, long-term and preventive clinical effects in children and adults: the effects of immunotherapy can be categorised by level of benefit -the centenary of allergen specific subcutaneous immunotherapy. Clinical and translational Allergy 2: 8.

16. Hurst DS, McDaniel A (2021) Clinical Relevance and Advantages of Intraderma Test Results in 371 Patients with Allergic Rhinitis, Asthma and/or Otitis Media with Effusion. Cells 10: 3224. Link: https://bit.ly/3DMV3Bp
Discover a bigger Impact and Visibility of your article publication with

\section{Peertechz Publications}

\section{Highlights}

* Signatory publisher of ORCID

* Signatory Publisher of DORA (San Francisco Declaration on Research Assessment)

* Articles archived in worlds' renowned service providers such as Portico, CNKI, AGRIS, TDNet, Base (Bielefeld University Library), CrossRef, Scilit, J-Gate etc.

* Journals indexed in ICMJE, SHERPA/ROMEO, Google Scholar etc.

- OAI-PMH (Open Archives Initiative Protocol for Metadata Harvesting)

* Dedicated Editorial Board for every journal

* Accurate and rapid peer-review process

* Increased citations of published articles through promotions

* Reduced timeline for article publication

Submit your articles and experience a new surge in publication services (https://www.peertechz.com/submission).

Peertechz journals wishes everlasting success in your every endeavours. 